\title{
CONSUMERS KNOWLEDGE ABOUT DIETARY FIBRE - RESULTS OF A SURVEY QUESTIONNAIRE IN HUNGARY AND ROMANIA
}

\author{
V. SZÜCS ${ }^{a *}, Z$ Z. FAZAKAS ${ }^{b}$, M. TARCEA $A^{b}$ and R. GUINÉ $\hat{c}^{c}$ \\ ${ }^{a}$ National Agricultural Research and Innovation Centre - Food Science Research Institute, H-1022 Budapest, \\ Herman Ottó út 15 . Hungary \\ buniversity of Medicine and Pharmacy, Gheorghe Marinescu Str., 38, 540139 Targu-Mures. Romania \\ ${ }^{\mathrm{c}}$ CI\&DETS/Escola Superior Agrária do Instituto Politécnico de Viseu, Viseu. Portugal
}

(Received: 16 December 2015; accepted: 9 March 2016)

Dietary fibres (DFs) are essential components of the balanced diet. Even though the adequate level of their consumption can be ensured from several natural (e.g. fruit, vegetables, legumes) and 'artificial' sources (e.g. functional foods), the consumed levels are below the recommendations. To analyse the Hungarian and Romanian consumers' knowledge level, their perceptions of the health benefits associated with fibre, as well as the recognition of the potential information sources, a survey questionnaire was conducted with the total of 713 consumers. Results showed that the level of knowledge about DFs was not adequate. Internet was found to be widely used and identified as one of the most appropriate information sources to encourage the consumption of DF. It was a favourable result that three-quarter of the respondents was interested in the topic of healthy food consumption; however, just less than half of them took into consideration the label information during their shopping decisions. To increase the consumption of DF and to support the responsibility and conscious consumer decisions steps must to be done (e.g. education of children, pointing out of the sources). For this purpose, modern information technology and communication channels fitting to the consumers' cultural and personal particularities can be utilized.

Keywords: dietary fibre, knowledge, consumption habits, food labelling

DF is a key component in healthy and balanced nutrition. Scientific studies confirm the important role of DF consumption in reducing the occurrence of several diseases (GRAY, 2006; KeNDALL et al., 2010). According to the World Health Organization (WHO), the average adult should eat $25 \mathrm{~g}$ of fibre per day (WHO, 2003). Because of the fibre intake is far below the recommendations, there is a 'fibre gap' worldwide (JonEs, 2014).

Depending on national dietary surveys, Hungarian and Romanian consumers' average fibre consumption was below the recommended value (Societea DE NUtRITIE DIN Romania, 2006; Szeitz-Szabó et al., 2011; SARKADi et al., 2012). However, the reference amount could be easily ensured by the proper consumption of fruit, vegetables, and whole grain foods (REICKS et al., 2014). Results of the global ACNielsen Online Consumer Opinion Survey show that only $38 \%$ of the European consumers purchase regularly whole grain and high fibre products. About a third of them (29\%) did not believe that high fibre products really offered additional health benefits as they claimed, and according to $12 \%$ they were too expensive (ACNIELSEN, 2005). In spite of the fact that consumers are aware of the link between eating and health (GRUNERT, 2005), and even though they gave great importance to the role of DFs in treatment and prevention of many diseases, the reported level of intake was found to be low (MARTinHo et al., 2013). Functional foodstuffs can be potential options to fill

\footnotetext{
* To whom correspondence should be addressed.

Phone: +36-1-796-0423; fax: +36-1-796-0449; e-mail: szucs.viktoria@nak.hu
} 
in the 'fibre gap', European consumers' emphasis on the naturalness of food products stand in the way of a more rapid proliferation of these products (GRUNERT, 2013). Furthermore, labels of these products - due to the complex labelling regulations and consumers requirements - are crowded by different logos and information. Consumers try to make simplified shopping decisions in order to avoid information overload and cognitive stress (GRUNERT, 2015). Sociodemographic characteristics are potential determinants of functional food acceptance (VERBEKE, 2005). Results of JezewSKA-ZychowicZ and Królak (2015) showed that women were more willing to eat cereal products enriched with fibre than men - the same can be observed in case of fruit and vegetables (AzAGBa \& Sharaf, 2011; Emanuel et al., 2012) -, as well as respondents with relatively better education expressed greater intension to consume cereal products enriched with fibre.

The present study intended to analyse the Hungarian and Romanian consumers' knowledge level, their perceptions of the health benefits associated with fibre, the role of label information during their shopping decisions, as well as the recognition of the potential information sources in order to ensure authentic recommendations.

\section{Materials and methods}

As a result of the data collection, a total of 713 valid questionnaires were received in case of the analysed countries (303 in Hungary and 410 in Romania). The youngest respondent was 18 years old in Hungary and in Romania, too, while the oldest participant was 66 in Hungary (median: 25) and 89 in Romania (median: 28).

For the data collection a validated questionnaire was used (MARTINHO et al., 2013; GUINÉ et al., 2014). In order to achieve equivalence between the source version and the target version of the questionnaire, a back-translation and a pretest was performed in both countries (BULLINGER et al., 1993). The data were analysed with the assistance of IBM SPSS Statistics 23.0 (mean, Skewness, Kurtosis, ANOVA, frequency, $\mathrm{Chi}^{2}$-test, Friedman test with Wilcoxon signes-rank test, K-means cluster analysis). Ranking of the information sources were evaluated with Friedman test, and Post hoc analysis with Wilcoxon signed-rank tests was conducted with the application of a Bonferroni correlation. A K-means cluster analysis was performed in order to explore differences amongst the consumers and to determine similar consumer groups.

\section{Results and discussion}

\subsection{Knowledge about food fibres}

As it was perceived by MARTinHo and co-workers (2013), both the Hungarian and the Romanian participants' knowledge levels were found to be insufficient about DFs. The exact sources of DFs, the WHO recommendation and also the two groups of DFs (soluble and insoluble) were only partly known by the respondents of the analysed countries. In spite of the low level of knowledge, the comparison showed that - except of the WHO recommendation - Romanian participants had more detailed knowledge than Hungarian ones. But these differences are not relevant enough to state that Romanian participants' level of knowledge would have been adequate (Table 1). 


\begin{tabular}{|c|c|c|c|c|c|c|c|}
\hline \multicolumn{4}{|c|}{ Hungary } & \multicolumn{4}{|c|}{ Romania } \\
\hline Mean & SD & Skewness & Kurtosis & Mean & SD & Skewness & Kurtosis \\
\hline \multicolumn{8}{|c|}{ Only vegetable foods have fibre. } \\
\hline $2.73^{\mathrm{b}}$ & 1.441 & 0.182 & -1.394 & $3.37^{\mathrm{a}}$ & 1.073 & -0.865 & -0.447 \\
\hline \multicolumn{8}{|c|}{ Foods of animal origin such as meat, eggs and dairy products contain no fibres (unless added). } \\
\hline $2.89^{\mathrm{b}}$ & 1.424 & 0.081 & -1.362 & $3.41^{\mathrm{a}}$ & 1.031 & -0.965 & -0.198 \\
\hline \multicolumn{8}{|c|}{ According to the WHO, the average adult should eat $25 \mathrm{~g}$ of fibre per day. } \\
\hline 3.56 & 0.964 & -0.520 & 0.294 & 3.64 & 0.734 & -1.029 & -0.451 \\
\hline \multicolumn{8}{|c|}{ Whole foods (e.g. pasta, rice, bread, cereal) have less fibre than non-whole foods. ${ }^{R}$} \\
\hline $2.17^{\mathrm{b}}$ & 1.321 & 0.826 & -0.552 & $1.92^{\mathrm{a}}$ & 0.760 & 1.210 & 2.419 \\
\hline \multicolumn{8}{|c|}{ The unpeeled fruit have less fibre than peeled ones. ${ }^{R}$} \\
\hline $2.24^{\mathrm{a}}$ & 1.392 & 0.721 & -0.902 & $1.77^{\mathrm{b}}$ & 0.771 & 1.550 & 4.299 \\
\hline \multicolumn{8}{|c|}{ Dietary fibres are classified into soluble and insoluble. } \\
\hline $2.43^{\mathrm{b}}$ & 1.143 & -0.334 & -0.468 & $2.59^{\mathrm{a}}$ & 1.307 & 0.415 & -1.088 \\
\hline
\end{tabular}

1: strongly disagree; 5 : strongly agree; ${ }^{\mathrm{R}}$ : Reversed item

Mean utilities with different superscript letters within a row ${ }^{(a, b)}$ differ significantly $(\mathrm{P}<0.05)$

\subsection{Relationship between DFs and diseases}

Participants of the countries agreed with the favourable health effects of DFs $\left(\right.$ Mean $_{\text {Hungary }}$ : 4.20; Mean $_{\text {Romania }}$ : 4.24) - as it was found by GRUNERT (2005) and MARTINHO and co-workers (2013). Preventive and treatment effect of fibre consumption in case of 'obesity' and 'bowel cancer' $\left(\right.$ Mean $_{\text {Hungary }}: 4.04,4.04$; Mean Romania $_{3.82,4.27)}$ were well known by the respondents of both countries. However, the connection of DF intake with the level of 'cholesterol', 'deficiency of vitamins and minerals', and 'diabetes' $\left(\right.$ Mean $_{\text {Hungary }}: 3.86,3.58,3.58$; Mean $_{\text {Romania }}$ : $3.72,3.63,3.45)$ was less known. The control questions refer to the beneficial effect of DF consumption to the prevention and/or treatment of 'breast cancer' and 'vision problems' (Mean $_{\text {Hungary }}: 2.79,2.81$; Mean Romania $_{3}$ 3.07, 2.85) showed that Hungarian participants were more thoughtful during rating of the statements. Even the level of knowledge showed a better familiarity of the Romanian participants, in most of the cases - expect the connection with 'bowel cancer' - Hungarian participants reported significantly $(\mathrm{P}<0.05)$ higher awareness of the beneficial health effects of DF intake. Nevertheless, as it was perceived in case of the knowledge about DFs this knowledge was still not adequately high.

\subsection{Food labelling}

Label and nutrition information was found to have higher importance during the shopping decisions of the Romanian participants. However, the importance of the fibre amount is a less determining factor in the food choice of these countries participants. Even though Romanian participants showed slightly more conscious shopping attitude, they were mistrustful against the signs that made an allusion to the high fibre content (Table 2). 


\begin{tabular}{|c|c|c|c|c|c|c|c|}
\hline \multicolumn{4}{|c|}{ Hungary } & \multicolumn{4}{|c|}{ Romania } \\
\hline Mean & SD & Skewness & Kurtosis & Mean & SD & Skewness & Kurtosis \\
\hline
\end{tabular}

When buying a food product I usually consult the label information.

$\begin{array}{llllllll}3.61^{\mathrm{b}} & 1.107 & -0.549 & -0.443 & 4.07^{\mathrm{a}} & 0.842 & -0.819 & 0.303\end{array}$

On the label, I usually consult the nutritional information.

$$
\begin{array}{llllllll}
3.19 & 1.135 & -0.122 & -0.767 & 3.26 & 1.235 & 0.038 & -1.027
\end{array}
$$

In the nutritional label of any food I usually check how much fibre it possesses.

$$
\begin{array}{llllllll}
2.25^{\mathrm{b}} & 1.111 & 0.555 & -0.512 & 3.07^{\mathrm{a}} & 1.206 & 0.150 & -0.824
\end{array}
$$

The amount of fibres is a factor to be taken into account in the choice of similar foods.
$2.18^{\mathrm{b}}$
1.215
0.757
$-0.437$
$2.80^{\mathrm{a}}$
1.149
$0.515-0.460$

If I buy a food product where the packaging refers to 'high fibre' or 'high in fibre', I check the label for the amount of fibre it has.

\begin{tabular}{lllllllll}
$2.41^{\mathrm{b}}$ & 1.298 & 0.446 & -1.014 & $3.06^{\mathrm{a}}$ & 1.513 & -0.275 & -1.425 \\
\hline
\end{tabular}

1: strongly disagree; 5 : strongly agree

Mean utilities with different superscript letters within a statement ${ }^{(\mathrm{a}, \mathrm{b})}$ differ significantly $(\mathrm{P}<0.05)$

\subsection{Information sources}

When participants of the survey were asked to rank the listed information sources according to their frequency where they had met information about DF (Hungary: $\lambda^{2}(5)=362.730$, $\mathrm{P}=0.001$; Romania: $\left.\lambda^{2}(5)=363.619, \mathrm{P}=0.001\right)$, 'internet' proved to be significantly the most important one. However, in Romania the 'television' got the same importance as the 'internet' $(\mathrm{Z}=2.708, \mathrm{P}=0.007)$. Hungarian participants met quite frequently with the topic of fibres in 'magazines, books' and 'television', too; however, 'health centres, hospitals', 'schools', and 'radio' were found to be less important sources for them. According to the Romanian ranking 'magazines, books' and 'radio' were moderately important sources of DF information, while

\begin{tabular}{|c|c|c|c|c|}
\hline & \multicolumn{2}{|c|}{ Hungary } & \multicolumn{2}{|c|}{ Romania } \\
\hline & Mean rank & SD & Mean rank & SD \\
\hline Internet & $4.89^{\mathrm{ax}}$ & 1.381 & $4.51^{\mathrm{bx}}$ & 1.798 \\
\hline Magazines, books & $4.17^{\text {ay }}$ & 1.502 & $3.54^{\mathrm{bz}}$ & 1.607 \\
\hline Television & $3.56^{z}$ & 1.486 & $4.19^{\mathrm{x}}$ & 1.429 \\
\hline Health centres, hospitals & $3.12^{\mathrm{zv}}$ & 1.744 & $2.53^{\mathrm{z}}$ & 1.604 \\
\hline School & $2.92^{\mathrm{bv}}$ & 1.466 & $2.69^{\mathrm{az}}$ & 1.524 \\
\hline Radio & $2.34^{\mathrm{bw}}$ & 1.338 & $3.54^{\text {ay }}$ & 1.291 \\
\hline
\end{tabular}
'schools' and 'health centres, hospitals' were the less important ones (Table 3).

1: the least important; 6: the most important

Mean utilities with different superscript letters within a row ${ }^{(a, b)}$ and with different superscript letters within a column ${ }^{(x, y, z, v, w)}$ differ significantly $(\mathrm{P}<0.05)$ 
Participants ranked the sources again according to what means of communication they considered to be the most appropriate to encourage the consumption of DF (Hungary: $\lambda^{2}$ $(5)=432.860, \mathrm{P}=0.001$; Romania: $\left.\lambda^{2}(5)=160.0101, \mathrm{P}=0.001\right)$. Hungarian participants ranked the 'internet' again to the first place. Importance of the 'magazines, books' seemingly decreased, but at the same time significance of 'school' increased notably. So for the Hungarian participants the education started in the childhood had high relevance. 'Health, centres' and 'radio' resulted again at the bottom of the list. Regarding the ranking of the Romanian respondents remarkable distinction was not made between the importance of 'radio', 'television', 'magazines, books' and 'internet'. Compared to the Hungarian results 'schools' received less importance, but 'health centres, hospitals' resulted also in the end of the gradation (Table 4).

\begin{tabular}{|c|c|c|c|c|}
\hline & \multicolumn{2}{|c|}{ Hungary } & \multicolumn{2}{|c|}{ Romania } \\
\hline & Mean rank & SD & Mean rank & SD \\
\hline Internet & $4.76^{\mathrm{ax}}$ & 1.349 & $3.68^{\text {by }}$ & 1.773 \\
\hline Magazines, books & $2.98^{\mathrm{bz}}$ & 1.383 & $3.69^{\text {ay }}$ & 1.364 \\
\hline Television & $4.04^{y}$ & 1.514 & $3.94^{\mathrm{xy}}$ & 1.875 \\
\hline Health centres, hospitals & $2.78^{\mathrm{z}}$ & 1.578 & $2.65^{\mathrm{w}}$ & 1.474 \\
\hline School & $4.26^{\mathrm{ay}}$ & 1.508 & $3.08^{\mathrm{bz}}$ & 1.823 \\
\hline Radio & $2.17^{\mathrm{bv}}$ & 1.324 & $3.96^{\mathrm{ax}}$ & 1.459 \\
\hline
\end{tabular}

1: the least important; 6 : the most important

Mean utilities with different superscript letters within a row ${ }^{(a, b)}$ and with different superscript letters within a column ${ }^{(x, y, z, v)}$ differ significantly $(\mathrm{P}<0.05)$

\subsection{Cluster analysis}

Analysing the level of health knowledge, 3-3 significantly $(\mathrm{P}<0.001)$ different clusters were created in both countries. In the Hungarian cluster structure the statements analysing the positive effect of DF consumption on 'bowel cancer' $(\mathrm{F}=124.094)$ and the control questions ('vision problem' $F=120.535$; 'breast cancer' $F=118.715$ ) had the strongest effect. Regarding the Romanian cluster, statements related to the connection with 'obesity' $(\mathrm{F}=438.768)$, 'vision problem' ( $\mathrm{F}=382.256)$, level of 'cholesterol' (364.614), and 'cardio-vascular diseases' $(\mathrm{F}=353.049)$ had a great importance (Table 5).

The in-depth analysis of the clusters showed similarities between the countries. In the groups with the largest number of members (Cluster 3; Hungary: $41 \%$, Romania: $49 \%$ of respondents) high importance was reported to the DF consumption in overall and to the level of knowledge about the listed health problems, too. However, they also attributed a high importance to the control items, so they found to be quite confining and conforming. Members of this cluster were mainly women, who - like the finding of JEZEWSKA-ZYCHOwICZ and KRÓLAK (2015) - pay attention to the label information, and for them fibre content of the foodstuffs determines the shopping decisions. Romanian members met with the topic in the 'radio' and on the 'television'; however, the 'internet' would be a better information channel for them to encourage the consumption of DF. 
Table 5. Consumer clusters based on the statements related to the heath knowledge

\begin{tabular}{|c|c|c|c|c|c|c|c|}
\hline \multicolumn{4}{|c|}{ Hungary } & \multicolumn{4}{|c|}{ Romania } \\
\hline Cluster 1 & Cluster 2 & Cluster 3 & $\mathrm{~F}$ & Cluster 1 & Cluster 2 & Cluster 3 & $\mathrm{~F}$ \\
\hline \multicolumn{8}{|c|}{ Eating dietary fibres in appropriate amounts can prevent and/or treat diseases. } \\
\hline 3.359 & 4.398 & 4.608 & 76.548 & 3.706 & 4.182 & 4.545 & 58.792 \\
\hline \multicolumn{8}{|c|}{ Fibres can prevent and/or treat cardio-vascular diseases. } \\
\hline 3.308 & 3.602 & 4.368 & 45.832 & 2.188 & 3.250 & 4.207 & 353.049 \\
\hline \multicolumn{8}{|c|}{ Fibres can prevent and/or treat cholesterol. } \\
\hline 3.218 & 3.724 & 4.376 & 48.585 & 2.247 & 4.016 & 4.197 & 364.614 \\
\hline \multicolumn{8}{|c|}{ Fibres can prevent and/or treat bowel cancer. } \\
\hline 2.910 & 4.347 & 4.496 & 124.094 & 4.635 & 3.742 & 4.485 & 37.605 \\
\hline \multicolumn{8}{|c|}{ Fibres can prevent and/or treat obesity. } \\
\hline 3.154 & 4.173 & 4.488 & 71.548 & 2.118 & 4.105 & 4.419 & 438.768 \\
\hline \multicolumn{8}{|c|}{ Fibres can prevent and/or treat breast cancer. ${ }^{\mathrm{C}}$} \\
\hline 2.744 & 1.827 & 3.584 & 118.715 & 2.259 & 2.508 & 3.808 & 213.368 \\
\hline \multicolumn{8}{|c|}{ Fibres can prevent and/or treat constipation. } \\
\hline 3.372 & 4.735 & 4.728 & 95.778 & 2.306 & 4.556 & 3.848 & 257.124 \\
\hline \multicolumn{8}{|c|}{ Fibres can prevent and/or treat vision problems. ${ }^{C}$} \\
\hline 2.718 & 1.867 & 3.608 & 120.535 & 2.235 & 1.790 & 3.808 & 382.256 \\
\hline \multicolumn{8}{|c|}{ Fibres can prevent and/or treat the deficiency of vitamins and minerals. } \\
\hline 3.282 & 2.990 & 4.208 & 38.527 & 3.659 & 2.766 & 4.202 & 112.918 \\
\hline \multicolumn{8}{|c|}{ Fibres can prevent and/or treat diabetes. } \\
\hline 3.077 & 3.122 & 4.248 & 53.919 & 2.282 & 3.169 & 4.157 & 153.768 \\
\hline
\end{tabular}

C. Control item

Almost one third of the countries' participants (Cluster 2; Hungary: 33\%, Romania: $30 \%$ ) reported the highest and the most confident level of knowledge about the DFs. Higher educated (university degree) respondents belonged to this cluster. Members of the Hungarian cluster did not deal with the label information (nutrition and fibre) on the food packaging. Their level of knowledge was not manifested in their shopping decisions, which result was not in line with the results of JezEwSKA-ZyChowicz and KrólaK (2015). On the 'internet' and 'radio' Romanian members frequently met with the topic; however, in the future they saw the importance of the education of 'schools' and less the 'internet'.

In the smallest group of both countries sample (Cluster 1; Hungary: 26\%; Romania: $21 \%)$ respondents had the lowest level of knowledge. The highest number of men participants belonged to this groups. Romanian members of this cluster showed the less conscious attitude during their shopping decisions. 'Internet' and 'television' were their present source of information, and in the future they saw a high potential in the 'television'.

As in Hungary the 'internet' was classified at the first place according to the ranking of the present information sources and the potential future ones, too, the clusters were not different according to its judgement. Furthermore, in all clusters high importance of the 'schools' was identified. 


\section{Conclusions}

Differences perceived in the level of knowledge regarding DFs do not verify the thorough or even detailed knowledge of the analysed countries' consumers.

Results of the analysis of the information sources showed that internet - which is quite difficult to control - is a universally used information source in the topic of nutrition (SzüCS et al., 2014, 2015). Modern information sources (e.g. mobile applications) can reduce the information overload on food labels and can help to deliver smart, reduced, and even personalized information to the consumers.

For adequate amount of DF intake, which is essential for the healthy and balanced nutrition exploration of the inhibitory factors (e.g. disliking, restricted availability) regarding their consumption is crucial. In order to support the responsibility and conscious consumer decisions education of children (e.g. reformulation of catering), it is important to point out the adequate natural fibre sources and to emphasize their importance and role during meal preparation as well as their alternative versions (e.g. functional foods). For this purpose, the use of modern information technology and communication channels fitting to the consumers' cultural and personal particularities can have a huge relevance, and due to the authentic and targeted knowledge transfer, consumers' latent knowledge expectedly will soon appear in their conscious food choice decisions.

This work was prepared in the ambit of the multinational project from CI\&DETS Research Centre (IPV - Viseu, Portugal) with reference PROJ/CI\&DETS/2014/0001, all authors were members of this project.

\section{References}

ACNielsen (2005): Functional Food \& Organics. A global ACNielsen online survey on consumer behaviour \& attitudes. Available at http://www2.acnielsen.com/reports/documents/2005_cc_functional_organics.pdf (last accessed: 24 November 2015)

Azagba, S. \& Sharaf, M. (2011): Disparities in the frequency of fruit and vegetable consumption by sociodemographic and lifestyle characteristics in Canada. Nutr. J., 10, 1-8.

Bullinger, M., Anderson, R., Cella, D. \& Aaronson, N. (1993): Developing and evaluating cross-cultural instruments from minimum requirements to optimal models. Qual. Life Res., 2, 451-459.

Emanuel, A.S., McCully, S.N., Gallagher, M.K. \& Updegraff, J.A. (2012): Theory of planned behavior explains gender difference in fruit and vegetable consumption. Appetite. 59, 693-697.

Gray, J. (2006): Dietary fibre. ILSI Europe. Available at http://www.ilsi.org/Europe/Publications/C2006Diet_ FibEng.pdf (last accessed: 24 November 2015)

Grunert, K.G. (2005): Food quality and safety: consumer perception and demand. Eur. Rev. Agric. Econ., 32, 369-391.

Grunert, K.G. (2013): Trends in food choice and nutrition. -in: Klopčič, M., Kuipers, A. \& Hocquette, J.F. (2013): Consumer attitudes to food quality products. Wageningen Academic Publishers, The Netherlands. pp. 23-30.

GRUNERT, K.G. (2015): 20 years of EUFIC - Consumer information paradox: the evolution of consumer motivations and behaviors. Food Today, The European Food Information Council Newsletter. Available at http://www. eufic.org/article/en/artid/20_years_of_eufic_consumer_information_paradox_the_evolution_of_consumer_ motivations and behaviours/ (last accessed: 26 November 2015)

Guiné, R.P.F., Marthinho, C.C., Barroca, M.J. \& Viseu, C.M. (2014): Knowledge and attitudes regarding dietary fibres: A consumer survey in Portuguese population. J. Basic Appl. Res. Int., 1(1), 1-12.

JezewsKa-Zychowicz, M. \& KrólaK, M. (2015): Do consumers' attitudes towards food technologies and motives of food choice influence willingness to eat cereal products fortified with fibre? Pol. J. Food Nutr. Sci., 65, 281291.

JoNES, J.M. (2014): CODEX-aligned dietary fiber definitions help to bridge the 'fiber gap'. Nutr. J., 13, 1-10. 
Kendall, C.W.C., Esfahani, A. \& Jenkins, D.J.A. (2010): The link between dietary fibre and human health. Food Hydrocolloid., 24, 42-48.

Martinho, C.A.C., Correia, A.C., Gonçalves, F.M.J., Abrantes, J.L., Carvalho, R. \& GuinÉ, R.P.F. (2013): Study about the knowledge and attitudes of the Portuguese population about food fibres. Curr. Nutr. Food Sci., 9, $180-188$.

Reicks, M., Jonnalagadda, S., Albertson, A.M. \& Joshi, N. (2014): Total dietary fiber intakes in the US population are related to whole grain consumption: Results from the National Health and Nutrition Examination Survey 2009 to 2010. Nutr. Res., 34, 226-234.

Sarkadi, N.E., Bakacs, M., Illés É., Zentai, A., Lugasi, A. \& Martos, É. (2012): Országos Táplálkozásés Tápláltsági Állapot Vizsgálat - OTÁP 2009 II. A magyar lakosság energia és makrotápanyag bevitele. (Hungarian diet and nutritional status survey - The OTAP 2009 study.). Orvosi Hetilap, 153, 1057-1067.

Societatea de Nutritie din Romania (2006): Ghid pentru alimentația sănătoasă. (Romanian Dietary Guidelines.) Editura Performantica, Isai. pp. 32-34.

Szeitz-Szabó, M., Bíró, L., Bíró, Gy. \& Sali, J. (2011): Dietary survey in Hungary, 2009. Part I. Macronutrients, alcohol, caffeine, fibre. Acta Alimentaria. 40, 142-152.

SzüCs, V., FüLöP, Á. \& JuhÁsz, Á. (2014): Analysis of age differences in the risk perception of food additives: Results of focus group interviews. Acta Univ. Sapientiae Alimentaria. 7, 96-108.

Szücs, V., SZABó, E. \& BÁNÁTI, D. (2015): Az egészséges táplálkozással kapcsolatos attitüdök feltárása kérdőíves felmérés alapján. (Exploration of healthy nutrition attitudes on the basis of a questionnaire survey.) Orvosi Hetilap, 156(16), 636-643.

VERBEKE, W. (2005): Consumer acceptance of functional foods: socio-demographic, cognitive and attitudinal determinants. Food Qual. Prefer., 16, 45-57.

WHO (2003): Diet, nutrition and the prevention of chronic diseases. Report of a Joint WHO/FAO Expert Consultation. WHO Technical Report Series 916, Geneva, pp. 54-60. 